\title{
An Overview of Affordable Low Cost Housing in Nigeria; a Case for Stabilised Compressed Earth Block (SCEB)
}

\author{
Anthony Maduabum ${ }^{1} \&$ Charles Munonye ${ }^{2}$ \\ 1,2 Department of Architecture, Chukwuemeka Odumegwu Ojukwu University, Uli, Nigeria
}

\begin{abstract}
Over the years, the Federal and State Governments of Nigeria mounted 'low-cost' housing schemes that were expected to be affordable to the low income earners. By the time some of these schemes were completed they were priced beyond the reach of the low-income earners, and even that of the middle-income earners. Various research works that looked into the failure of the provision of the 'low-cost' housings in Nigeria found out that the reason for the failure are political interference and corruption. This paper overviewed the various building materials used in building construction and concluded that the objectives of providing housing affordable 'low cost' housing schemes in Nigeria can be achieved if local building materials such as Stabilized Compressed Earth Block (SCEB) is used in the construction. The paper concludes that if professionals in the building sector are given the free will to do their jobs, it will also enhance the objective of providing affordable 'low cost' houses.
\end{abstract}

\section{INTRODUCTION}

As at the resumption of democratic governance 1999, it was estimated that about $60 \%$ of Nigerians were homeless, (ABDULKARIM, 2005). The United Nations General Assembly in 1988 adopted the Global Strategy for Shelter (GSS) to the Year 2000 which of course failed to achieve its aim of 'Housing for all by the year 2000. According to the United Nations Survey for the decade, 1991 - 2001, the required output to meet the Housing Need of Nigeria was 7,363,000 at the rate of 736,300 annually which is a far cry from the less than 1000 units achieved by the main Government Housing Agency, (UN-HABITAT, 2006). This shows clearly that the government could not meet up and because of this, the GSS called on publicsector agencies to concentrate on creating an enabling environment for the private sector to step in and ensure the availability of adequate shelter for all. In 1991, the Nigerian National Housing Policy was promulgated in order to propose solutions to housing problems, with the basic goal of providing affordable housing to the people (Ibimilua \& Amos, 2015). The Nigerian National Housing Policy (NNHP) of 1991 has the following objectives:

$>$ Encouraging and promoting active participation in housing delivery by all tiers of government;

$>$ Strengthening institutions within the system to render their operations more responsive to demand;
$>$ Emphasizing housing investments which satisfy basic needs;

$>$ Encouraging greater participation by the private sector in housing delivery

This has largely been successful as there is today a thriving private sector driven housing effort that has seen to the production of numerous estates in Abuja and in other parts of Nigeria, (NHP, 1991).

As has been the usual outcome, the middle class remains homeless or "under housed" in the urban environment because these housing schemes are profit driven and therefore beyond the reach of the average urban dweller. By contrast, as late as the 1980s, a University graduate fresh from the National Youth Service Corps, NYSC could afford a standard three bedroom house, and a brand new Peugeot 504 all based on his monthly salary, while his counterpart of 2020 would be lucky to get a job after 3 years of NYSC, that will afford him a 1 bedroom house in places where such privilege obtains, otherwise you are on your own. There should therefore be a conscious effort to achieve real 'low cost' housing in our urban environment, this will gradually bring to extinction the slum-squatter arrangement and improve the quality of the urban and surrounding environments. It will in turn improve the quality of life of the Nigerian public, the Gross Domestic Product Output will improve, and coverage in social service delivery and revenue recovery from housed persons would be enhanced. Housing the citizens will help in crimes control, resources planning, development, utilization, conservation and management. This is because; spatial aspects of human activities are major determinants of the overall environmental quality and demographic factors help in proper service delivery planning. This brings the concept of per capita modeling and carrying capacity of territories into focus, without which sustainability in the urban environment cannot be attained and the system is bound to fail due to pressure from overflows. The concept of resource impact index for water and of course urban groundwater according to Ibezue, (2013), in a linear regression model, showed that water impact index has direct bearing on land use. Her findings makes a case for integrated planning of resources to ensure that no one resource is developed at the expense of the other; as such lopsided policy are not just unattainable but unsustainable. At least $30 \%$ of the world's population are estimated to live in earth buildings, mostly 
scattered throughout Africa, Central America and the Middle East (Manson et al, 2016), and South West USA. The renewed interest in earth as a building material emerged with the recent concerns of more sustainable friendly construction material (Bogas et al, 2019).

\section{* Definitions of Terms}

The Advanced Learner's English Dictionary defines Earth simply as Soil.

Soil: Ground, earth, especially the upper layer of earth in which plants, trees etc. grow. Earth: Soil, the loose material that covers the land surfaces of the Earth and supports growth of plants, (ENCARTA, 2007)

From the foregoing, it is clear that the terms-earth and soil can used interchangeably for our purposes. Soil therefore is a layer of loose material, varying in thickness over the Earth's crust, formed from bed-rock after a very long process of weathering and the complex migration of particles. There are numerous of types of soil, with variations in characteristics, and when they contain little organic matter, they can be used for building purposes.

Earth is one of the most ancient building materials known to man. In Mesopotamia (present-day Iraq), in the Indus valley (India), along the banks of the Huanghe (China) and the Nile (Egypt), the main cradles of civilization earthen Architecture was prevalent. About 30\% of the world's population live in earth-made construction and approximately $50 \%$ of the population in developing countries, including the majority of the rural population and at least $20 \%$ of the urban and suburban population, live in earthen dwellings (Houben et al, 1994). These figures though worldwide, do not represent the situation in Nigeria where even the poorest man dreams of 'upgrading' from an earthen house to a concrete house. Skilled technicians (architects and engineers) are generally not involved in this type of construction; hence the term, "non-engineered construction," is used to describe the result. Figures 1-5 show the various buildings where earth building materials were used in their construction.

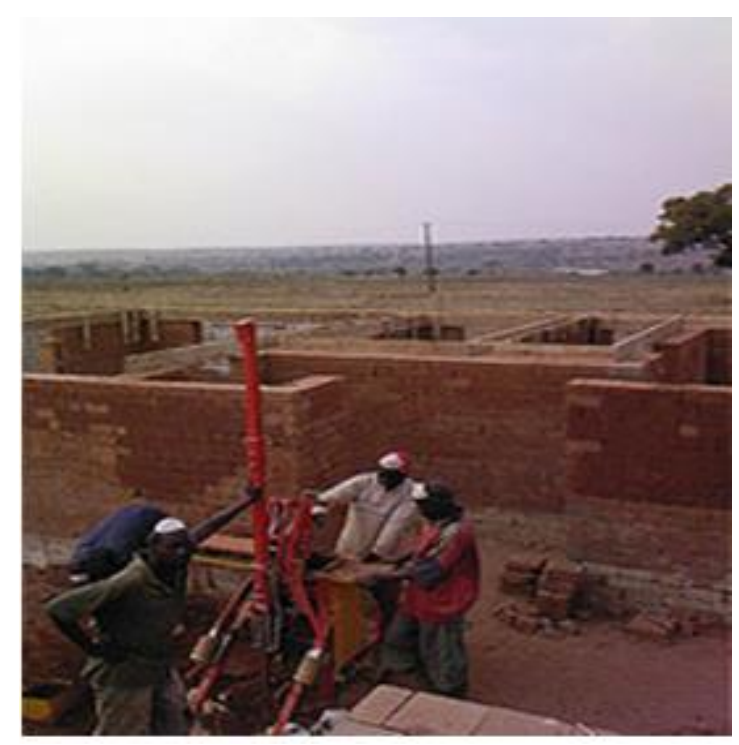

Fig 1:- Operating the Press in Zambia

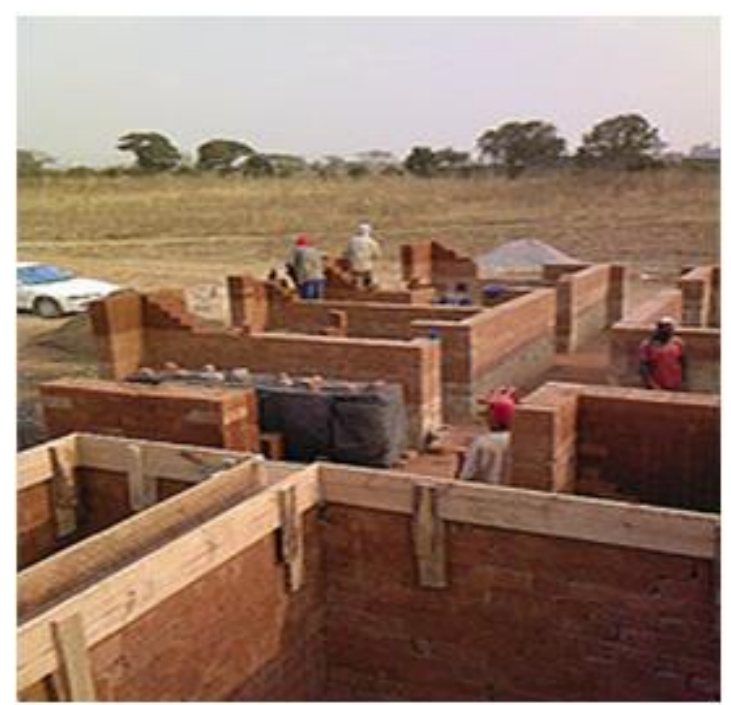

Fig 2:- House under construction in Zambia 


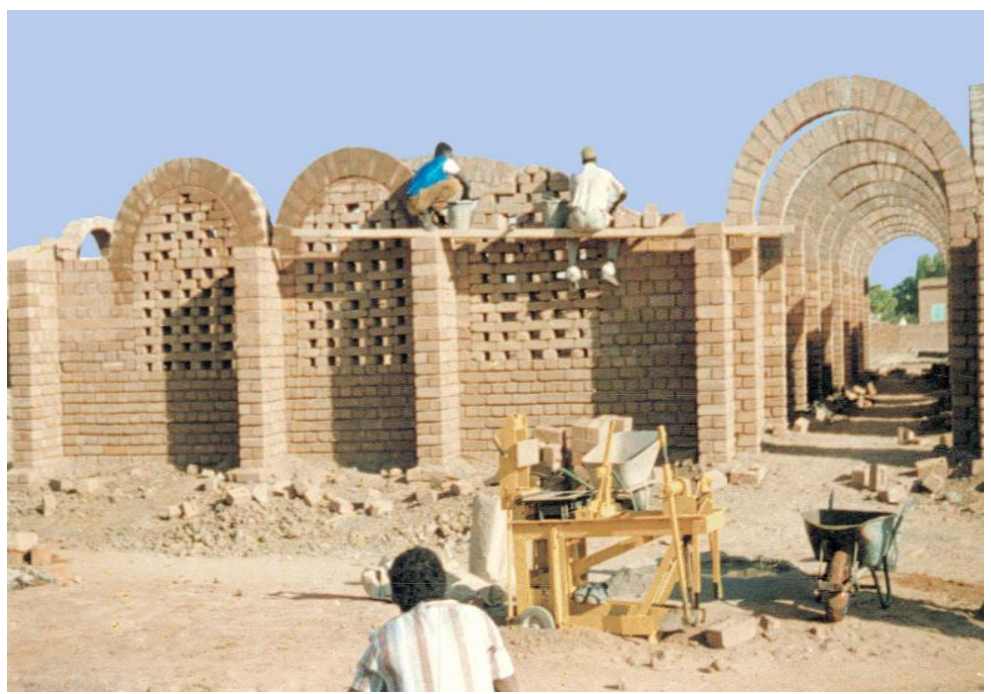

Fig 3:- Construction Site in Sudan Observe the Arches

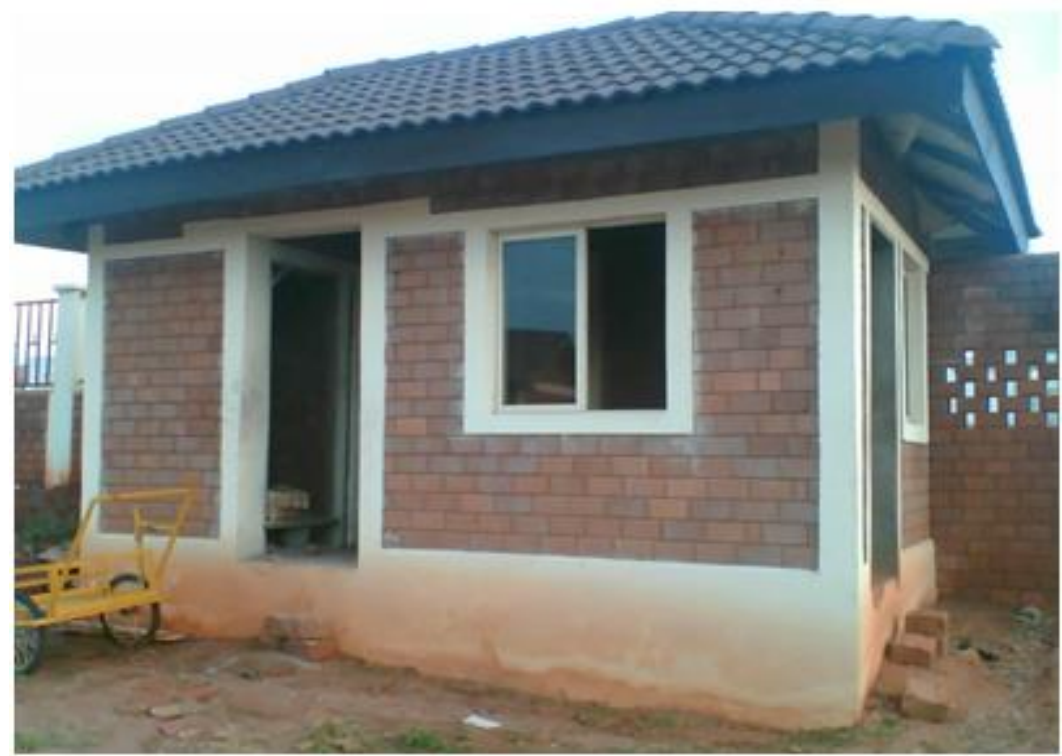

Fig 4:- Gatehouse in Awka (Nigeria)

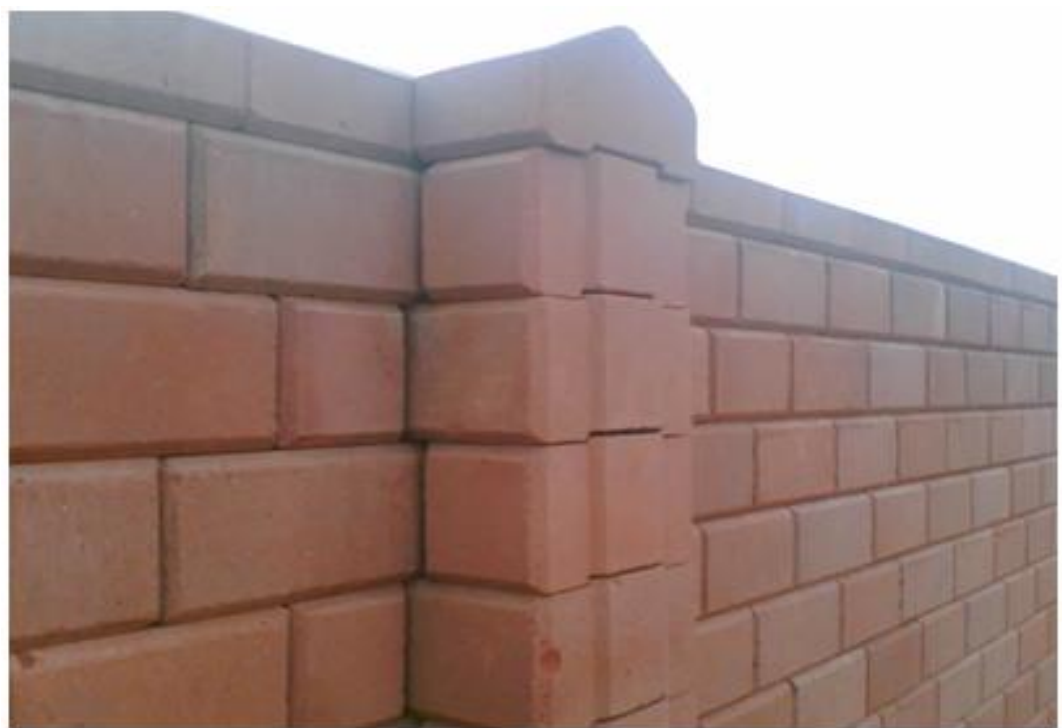

Fig 5:-.Fence in Awka (Nigeria) 


\section{TYPES AND SOURCES OF EARTH CONSTRUCTION RAW MATERIALS}

There are many types of walling materials like concrete, timber, bamboo, stone, metals, and the most popular around us, sandcrete (mixture of sand, cement and water) blocks. Recently, polystyrene panels are gaining ground but the most historical and universal is - Earth.

Adobe: Adobe is a natural building material made from sand, clay, and water, with some kind of fibrous or organic material (sticks, straw, dung), which is shaped into bricks using frames and dried in the sun. Usually adobe is shaped into bricks that can be stacked to form walls.

Rammed Earth or Pise-de-terre: Pise-de-terre resembles modern poured-concrete technology. Wooden frames are filled with wet earth, which is compressed with hammers. Sticks, straw, and hair bind the mud and increase the strength of the wall.

Wattle and Daub: A building material consisting of wattle work of vertical wooden posts driven into the ground with horizontal strips of sticks tied together with rope and covered with mud or clay. (Encarta, 2007)

\section{$>$ Merits of Earth as Building Material}

Availability - Earth or Soil is easily available being literally, beneath our feet. Suitable soil for building is found almost everywhere.

Affordability - Because soil is readily available, it is cheap to acquire. When labor and materials are used resourcefully, an affordable earth building is realized.

Energy Efficient - A well-built earthen building possesses a high thermal mass enabling the house to stay cool in hot weather and warm in cool weather -a mystery of sorts.

Sustainability - Earth is a renewable resource and therefore offers a sustainability advantage. This is an example of appropriate construction technology methods/practices that help protect the natural environment, make use of local resources and contribute to local economic empowerment.

Fire Resistance - The fire rating of the earthen wall is high, performing better than the popular steel and concrete.

Chemical Resistance - Earthen structures are mostly resistant to corrosion and chemical activity. They are therefore preferable in certain industrial environments.

Environmental Friendliness - The raw material is extracted from the earth and is returned to the earth after a long period of use in a low impact manner. It is biodegradable and non toxic.
Durability - An earthen building when well-built is extremely durable. Some national monuments in Nigeria like Lord Lugard Gate Lodge, Kaduna -1901, Main Post Office, Enugu - 1920, First Magistrate Court, Kaduna 1920, and Native Authority Treasury, Borno - 1926, are all built with earth. (CHUKWUALI, 1997).

Aesthetically Pleasing - Earth Block buildings can be made to look like any kind of finished structure; however, most people who opt for this type of construction find they love the look of the block itself and the adobe look of a finish plaster. Exteriors typically are given a weatherresistant skin which can be colored or left natural and interiors plastered with a variety of mixtures or left exposed. Arches and rounded corners are an option that allow for flexibility in design. They have a look and a feel that envelops their occupants and blends beautifully with the natural world.

\section{$>$ Demerits of building with earth}

There are of course, obvious disadvantages of earth as a building material some of which are:

Poor Tensile Strength - Although good in compression, earth has poor tensile strength. Its use is therefore limited to walls and floors.

Water Absorption - Walls made of naturally occurring earth absorb moisture easily and are therefore prone to wetness and even disintegration. They therefore require protection from moisture either from rain, ground water or bath water.

Abrasion - Earth is granular and brittle and therefore generates dust easily. Earthen buildings therefore require constant maintenance unless covered with protective plaster.

Negative Perception - The greatest problem with earth building is the negative perception that has been attached to it over the years. It is seen as a material for the poor and for the past. In years past, during the oil boom years in Nigeria, and with the craze for imported materials, the ambition of every young man was to make money and replace his father's mud house. Today, the disappearance of our grandfathers' mud houses is accomplished that even case studies are difficult to come by.

\section{$>$ Prospects for Earth Building}

According to Abdulkarim, (2005) one of the key aspects of the Nigeria's new National Housing Policy is to 'Promote the use of locally produced building materials as a means of reducing housing construction costs, by the government setting an example'. The following measures will be found useful in this regard:

Recognition of earth as an alternative building material. This has been achieved by the Nigerian National Building Code recognizing Sun dried soil bricks/blocks in Section 10.23 (NBC 2006). 
Standardization: The Standards Organization of Nigeria is in the process of preparing the Standard for Compressed Earth Blocks which is in 11 Parts and the Code of Practice which is in 3 Parts (NIS 2005).

Adoption of earth in design by the allied professions in the building industry. The Nigerian Institute of Architects (NIA) is right now articulating a Building Materials Policy. The Biennial General Meeting of the NIA which held in November 2009 had as it theme "Towards a Building Materials Policy".

Setting the Example: Government needs to set the example by using this cheap technology in some of its projects to illustrate to the public that it is acceptable.

Development Control needs to enforce the standards and regulations to improve the appearance and environment of earth buildings.

\section{Compressed Earth Blocks (CEB)}

At this point we also want to mention the improved technologies which people may find more acceptable Compressed Earth Blocks and Stabilized Compressed Earth Blocks.

Attempts to solve the problem of tensile weakness and thereby durability, aesthetics, standardization of the Adobe led to the idea of compaction. This compaction by means of a press was borrowed from the ceramics industry. The need to conserve the energy hitherto used for firing accelerated the development of the compressed earth block.

\section{- CEB Mortar}

Mortar for Compressed Earth Blocks is made from exactly the same material as the block itself. This ensures perfect bonding.

\section{- CEB Plaster}

Unlike the mortar, CEB plaster need not be the same material. In fact a stabilized mortar is more suitable because a completely earthen wall will be susceptible to erosion and therefore needs protection.

\section{> Gains of CEBs}

Consistency: of quality of the products obtained, thereby furthering the social acceptance of a renewal of building with earth.

- Very easily assimilated where the building tradition already relies on small masonry elements (fired bricks, stone, sand-cement blocks).

- Fine architectural quality of well-designed and wellexecuted compressed earth block buildings.

- Good compressive strength due to higher density by compaction of the blocks.

- Resistance to Corrosion and abrasion significantly increased by the higher density.

\section{$>$ CEB Limitations}

- The quality depends on good soil selection and preparation and on the correct choice of production material.

- Professional skills must be ensured by suitable training for architects and builders.

- CEBs can sometimes fail to be competitive with other local materials due to several factors. A technicaleconomic survey will enable the feasibility of the technology to be determined in each application context, (RIGASSI, 1985)

\section{$>$ Stabilised Compressed Earth Blocks (SCEB)}

The Stabilised Compressed Earth Block is a further improvement on the CEB. Stabilisation means the modification of the properties of soil by adding another material to improve its durability. The technology has been used for decades in road construction. The gains of stabilization are as follows:-

- Strength and Cohesion of the soil is increased

- Permeability of the soil (by water) is be reduced

- The soil becomes water repellent

- Durability of the soil is increased

- Expansion and Shrinking in wet conditions is reduced (ADAM 2001)

\section{$>$ Methods of Soil Stabilisation}

Mechanical Stabilisation: This involves the use of heavy weights to increase the density of the soil by reducing the air volume. This has the effect of reducing permeability and increasing compressive strength. Compression itself is a form of stabilization.

Cement Stabilisation: Portland cement hydrates when water is added to it producing a gel that hardens quickly. When cement is added to the soil and hydrated, it makes the soil water resistant by reducing swelling and increasing its compressive strength.

Other Stabilisers: Apart from cement, other stabilizing agents are, lime, bitumen, gypsum, pozzolanas, animal dung, anthill materials, bird droppings, plant extracts, and animal blood. At the Adobe USA Conference of 2009 a Nigerian researcher identified two local stabilizers - juice gum from grewia mollis plants and the kubawa fruits.

\section{> Interlocking Stabilised Earth Blocks}

This is what I consider the ultimate progression in the earth building field. After successfully achieving the SCEB there were still two problems - need for masonry skills to lay the blocks and the quantity of cement used for mortar. These two had individual and combined effects of increasing the cost of building. The Human Settlements Division of the Asian Institute of Technology along with the Thailand Institute of Scientific and Technological Research modified the CINVA-RAM machine used for compression thus creating the first Interlocking Earth Blocks. This interlocking system eliminated mortar and skilled labor thereby considerably reducing the cost of 
construction and enhanced the structural stability of the wall, (UN-HABITAT, 2009). This product is truly marvelous and it has found acceptance all over the world. It has been used in Nigeria, Angola, Uganda, Zambia, Mozambique, Ethiopia, Malawi, Mali, Madagascar, Ghana, Sierra Leone, Liberia, Mexico and USA, India etc.

\section{$>$ Reducing the Cost of Building}

The following strategies can help reduce the cost of building towards achieving a low cost house.

- Sound Architectural Design avoiding superfluity and unnecessary grandeur

- Reorientation of values to discourage ostentation

- Research into cheaper technologies. Nigerian Building and Road Research Institute, NBRRI and Building and Road Research Institute BRRI in Ghana can improve on their efforts in looking for cheaper ways of achieving the same thing.

- Site production of building components thus reducing transport costs

- Bulk Purchase of Building Materials

- Elimination of middlemen

- Avoid contracts if you can do direct labor

- Standardization of products

- Prefabrication can also save material and time.

- Use locally available materials

- Avoid expensive or 'Ego' materials like aluminum windows etc

- Take care of individual building elements like :

$\checkmark$ Earth for walls

$\checkmark$ Channel earth brick for lintels

$\checkmark$ Floor brick in place of concrete

$\checkmark$ Fiber-concrete roofing tiles (Akinrolabu, 2006)

\section{CONCLUSION}

Housing is one of the basic needs of humanity. The Nigerian housing policy was conceived in good faith with intention of providing cheap and affordable housing to the people, especially the low income earners. The fact remains that using local earth materials in the construction of buildings in Nigeria will help in reducing the overall cost, and will make the houses affordable and cheaper.

\section{REFERENCES}

[1]. Abdulkarim, M (2005). Policy Issues ion Mass Housing Delivery and Prospects of Assisted Self Help Schemes. Journal of the Nigerian Institute of Architects Vol 4 No 4

[2]. Adam, E.A. (2001). Compressed tabilised Earth Block Manufacture in Sudan. UNESCO, Paris

[3]. Akinrolabu, R.'B. (2006). Build Your Own House. Bolyn Construction Co. Ltd. Lagos

[4]. Bogas, J; Siva, M; \& Gomes, M. (2019). Unsterilized and stabilized compressed earth blocks with partial incorporation of recycled aggregates. Inter' Jour' of Architectural Heritage, 1=13 (4), 569-584.
[5]. Chukwuali C.B. (1997). Problems of Brick Production and Utilisation in Nigeria. AARCHES Journal, Vol. I, No 4.

[6]. "Earth" Microsoft ${ }^{\circledR}$ Encarta ${ }^{\circledR}$ 2007. C 1993-2006 Microsoft Corporation

[7]. Federal Ministry of Works and Housing (1991). National Housing Policy. Lagos. Federal Government of Nigeria

[8]. Federal Republic of Nigeria (2006). National Building Code. LexisNexis Butterworths, Durban.

[9]. Fegley, R.(2006). "African Mud Architecture" in Microsoft Encarta 2007. Microsoft Corporation.

[10]. Houben H. and Guillard H. (1994). Earth Construction - A Comprehensive Guide. Intermediate Technology Publications, London.

[11]. Ibezue, V.C. (2013). Water Impact Index as a Function Of Land Use. Journal of Applied Global Research, Volume 6, Issue 16.

[12]. Ibimilua, A. \& Amos, F. (2015). Housing policy in Nigeria. An overview. American Int' Journal' of Contemporary Research 5 (2), 53-59.

[13]. Mansour, M; Jelidi, A ; Cherif, A \& Jabrallah, S. (2016). Optimizing thermal and mechanical performance of Compressed Earth Blocks (CEB) Construction and Building Materials, (104), 44-51

[14]. Rigassi, V. (1985). Compressed Earth Blocks: Manual Of Production, Volume I. A Publication Of The Deutsches Zentrum Für Entwicklungstechnologien Gate In: Deutsche Gesellschaft Für Technische Zusammenarbeit Gtz) Gmbh in Coordination With BASIN.

[15]. Standards Organisation of Nigeria (2005). Standard for Compressed Earth Blocks. (Unpublished Draft)

[16]. The Bible, Recovery Version (1991). Exodus. Living Stream Ministry, Anaheim, California.

[17]. The Bible, Recovery Version (1991). Matthew. Living Stream Ministry, Anaheim, California.

[18]. UN-Habitat (2006). National Trends in Housing Production. Vol 4: Nigeria. UN-Habitat

[19]. UN-Habitat (2009). Human Settlements in Crisis: Interlocking Stabilised Soil Blocks. UN-Habitat, Nairobi. 